\title{
In vitro evaluation of fluoride products in the development of carious lesions in deciduous teeth
}

\section{Lucineide de Melo Santos(a) José Ivo Limeira dos Reis ${ }^{(b)}$ Maria Perolina de Medeiros ${ }^{(c)}$ Sheyla Moreira Ramos(c) Juliane Mendes de Araújo(c)}

(a) Adjunct Professor, Discipline of Pediatric Dentistry; ${ }^{(b)}$ Adjunct Professor, Discipline of Restorative Dentistry; (c) Undergraduate Student - School of Dentistry, Federal University of Alagoas (UFAL), Maceió, AL, Brazil.

\author{
Corresponding author: \\ Lucineide de Melo Santos \\ Faculdade de Odontologia, Universidade \\ Federal de Alagoas (FOUFAL) \\ Av. Lourival Melo Mota, s/n - Tabuleiro \\ do Martins \\ Maceió - AL - Brazil \\ CEP: 57072-970 \\ E-mail: jilreis@uol.com.br
}

Received for publication on Aug 06, 2008

Accepted for publication on Oct 28, 2008

\begin{abstract}
The purpose of this study was to evaluate the effect of the application of fluoride products on the development of enamel caries in deciduous teeth. A total of 108 deciduous teeth were chosen for the study. Acid-resistant varnish was applied on the teeth, leaving only one area of $5 \mathrm{~mm} \times 1 \mathrm{~mm}$ of dental enamel exposed. The teeth were allocated randomly to one of the following groups: 1) control - toothpaste without fluoride; 2) 1.23\% fluoride gel; 3) Duraflur fluoride varnish; 4) Duraphat fluoride varnish; 5) Fluorniz fluoride varnish; 6) Fluorphat fluoride varnish; 7) varnish with Duofluorid; 8) 12\% silver fluoride diamine (Cariestop); 9) children's fluoride toothpaste (500 ppm). The tested products were applied on the teeth according to the manufacturer's recommendations and the teeth were stored in a moist environment for 24 hours. Each group of teeth was then subjected to a $\mathrm{pH}$ cycling model for 14 days, after which the teeth were cut through the center for an analysis of the depth of the carious lesion by polarized light microscopy. Comparisons were made between the treatments and the control group. The mean lesion depth values were $318 \mu \mathrm{m} \pm 39$ (control), $213 \mu \mathrm{m} \pm 27$ (fluoride gel), $203 \mu \mathrm{m} \pm 34$ (Duraflur), $133 \mu \mathrm{m} \pm 25$ (Duraphat), $207 \mu \mathrm{m} \pm 27$ (Fluorniz), $212 \mu \mathrm{m} \pm 27$ (Fluorphat), $210 \pm 28$ (Duofluorid), $146 \pm 31$ (Cariestop) and $228 \pm 24$ (fluoride toothpaste). None of the products used here was able to completely prevent the formation of lesions. The highest cariostatic effect was achieved by fluoride varnish Duraphat and the lowest by the fluoride toothpaste.
\end{abstract}

Descriptors: Fluorides; Dental caries; Deciduous tooth. 


\section{Introduction}

Despite the changes in the paradigms of Dentistry, whereby preventive measures replace isolated restorative treatment and the treatment of the disease substitutes the treatment of signs and symptoms, dental caries is still the principal dental disease. ${ }^{1}$

Some authors have highlighted the multifactorial nature of caries, emphasizing the combination of biological, environmental and behavioral factors. ${ }^{2}$ The high consumption of sugars, especially saccharose, the absence of fluoride therapy and poor oral hygiene have been indicated as risk factors for the development of dental caries. ${ }^{3}$

The most common clinical expression of dental caries disease in young children is ECC (Early Childhood Caries), which is characterized by the involvement of deciduous teeth as soon as they erupt. ${ }^{4}$ ECC is a serious public health problem that affects both developing and industrialized countries. ${ }^{5}$

In addition, the literature reports that 1- to 3year-old children who ingest fluoride toothpaste become highly susceptible to develop fluorosis. ${ }^{6}$ Hence, there is clearly a need for a differentiated treatment philosophy involving preventive and therapeutic measures to prevent the appearance of new lesions, deter existing ones, and prevent the development of fluorosis. In this context, the rational use of fluoride is crucial. ${ }^{7}$ According to Chedid $^{8}$ (1999), the anticaries effect is not impaired when a minimum amount of fluoride toothpaste is used by children at the age of risk of developing fluorosis.

The topical application of substances containing high concentrations of fluoride on tooth surfaces, such as varnishes, gels and silver diamine fluoride, leads to the deposition of calcium fluoride and silver phosphate, in the case of diamine. The dissolution of these compounds is responsible for the cariostatic effect of these substances. ${ }^{9}$ It is believed that the slower this dissolution, the greater the cariostatic effect, which can be achieved through the application of silver diamine fluoride. ${ }^{10}$

In addition to these properties, the low cost of silver diamine fluoride, its easy application, short clinical time, and halting of dentinal sensitivity, which is very common in ECC, are factors that render it a viable alternative for use in pediatric dentistry, especially in economically less-favored regions. On the other hand, fluoride varnishes are another option, although imported varnishes cost four to eight times more than national ones. However, several reports have confirmed their effectiveness, ${ }^{11,12,13,14,15}$ which is not the case of national varnishes. The use of fluoride products has been the object of research in permanent teeth and, to a lesser extent, in deciduous teeth. Thus, the aim of the present study was to investigate the effect of fluoride products in the development of caries in the enamel of deciduous teeth using polarized light microscopy, and assess which of the fluoride products have the highest ability to prevent the development of enamel caries in deciduous teeth.

\section{Materials and Methods}

One hundred and eight caries-free deciduous teeth were selected, devoid of stains or any other defects visible under a stereoscopic magnifying glass. The teeth were supplied by the tooth bank of the School of Dentistry, Federal University of Alagoas. After their selection, the teeth were immersed in $0.1 \%$ thymol and stored in a refrigerator until their use.

Before using the teeth, they were cleaned with pumice and water, after which they were distributed into random groups, as follows: 1) control - toothpaste without fluoride; 2) fluoride gel (1.23\% FFA, Nupro, Dentsply, Petrópolis, RJ, Brazil); 3) Duraflur ${ }^{\circledR}$ varnish $(2.26 \%$ F, Herpo, Dentsply, Petrópolis, RJ, Brazil); 4) Duraphat ${ }^{\circledR}$ varnish $(2.26 \%$ F, Woelm \& Pharma Co., Eschwege, Germany); 5) Fluorniz ${ }^{\circledR}$ varnish $(5 \% \mathrm{NaF}$, SS White, Rio de Janeiro, RJ, Brazil); 6) Fluorphat ${ }^{\circledR}$ varnish (NaF-Inodon, Curitiba, PR, Brazil); 7) Duofluorid ${ }^{\circledR}$ XII varnish (FGM, Joinville, SC, Brazil); 8) 12\% Silver fluoride diamine (Cariestop ${ }^{\circledR}$ - Biodinâmica, Botucatu, SP, Brazil); 9) Children's fluoride toothpaste $(500 \mathrm{ppm}$ F, Colgate Baby, Colgate-Palmolive, Osasco, SP, Brazil). Each group consisted of 12 teeth. A layer of acidresistant varnish was applied on all the faces of the teeth, leaving only one $5 \times 1 \mathrm{~mm}$ area of enamel exposed. ${ }^{16}$ The fluoride products were applied according to the manufacturers' instructions and the treated teeth were stored for 24 hours in a moist 
environment. This storage period was followed by prophylaxis using pumice stones and deionized water, after which the groups were subjected to $10 \mathrm{pH}$ cycles for 14 days, as proposed by Chedid ${ }^{8}$ (1999). To this end, the teeth were immersed for 3 hours in a demineralizing solution $(2.0 \mathrm{mM}$ of calcium and phosphate in $75 \mathrm{mM}$ acetate buffer at $\mathrm{pH} 4.3$ ) at a temperature of $37^{\circ} \mathrm{C}$. The teeth were then washed in deionized water, dried with paper towels and placed in a container with a remineralizing solution (calcium $1.5 \mathrm{mM} / \mathrm{L}$, phosphate $0.9 \mathrm{mM} / \mathrm{L}$, potassium chloride $150 \mathrm{mM} / \mathrm{L}$, and cacodylate buffer $20 \mathrm{mM} /$ $\mathrm{L}, \mathrm{pH}$ 7.0), where they were left for 21 hours.

Before and after immersion in the demineralizing and remineralizing solutions, groups 1 and 9 were treated with the dentifrice. The other groups received a second application of their respective products after 7 days. The de- and remineralizing solutions were changed daily to prevent depletion or saturation of the solution and accumulation of enamel dissolution products. After the $\mathrm{pH}$ cycles, the teeth were cut with a double-faced diamond disk coupled to a cutting machine and prepared for analysis by polarized light microscopy to determine the presence or absence of carious lesions and the depth of the lesions. Comparisons were made of the average depth of each treatment and the control group and between the groups. The data were analyzed statistically by variance analysis (ANOVA) and Tukey's multiple comparison test with a $5 \%$ level of significance. This work was approved by the Ethics and Research Committee of the Federal Uni- versity of Alagoas (UFAL), under process number 000067/2006-99.

\section{Results}

The fluoride products used here augmented the reduction of the depth of the lesions when compared with the control group, and this difference was statistically significant $(\mathrm{p}<0.05)$ (Table 1$)$. The reduction varied from $28 \%$ to $58 \%$.

Among the fluoride varnishes, there was a variation of $58 \%$ to $33 \%$ in the reduction of lesion depth. A statistically significant difference $(\mathrm{p}<0.05)$ of $25 \%$ was found between the varnish with the lowest cariostatic effect and the varnish with the highest effectiveness in reducing carious lesions.

The effect of Duraphat ${ }^{\circledR}$ fluoride varnish and Cariestop ${ }^{\circledR}$ silver diamine fluoride did not differ significantly ( $p>0.05$ ); however, they showed a statistically significant difference $(\mathrm{p}<0.05)$ when compared with the other fluoride products.

The comparison between the fluoride toothpaste and acidulated phosphate fluoride revealed a difference of $5 \%$ in the reduction of lesion depth, although this difference was not statistically significant $(\mathrm{p}>0.05)$.

\section{Discussion}

The enamel of deciduous teeth is only half as thick as that of permanent teeth. ${ }^{17}$ Moreover, it has a lower mineral content and higher organic content, ${ }^{18}$ rendering it more susceptible to carious lesions than the enamel of permanent teeth. ${ }^{17}$

\begin{tabular}{|c|c|c|c|}
\hline & & & \\
\hline $\begin{array}{l}\text { Table } 1 \text { - Effect of fluoride } \\
\text { products on the in vitro }\end{array}$ & Group & $\begin{array}{l}\text { Average depth }(\mu \mathrm{m}) \text { of the } \\
\text { lesion } \pm \text { standard deviation }\end{array}$ & $\begin{array}{l}\text { Reduction of lesion depth } \\
\text { compared with the control group }\end{array}$ \\
\hline ent of carious lesions in & Dentifrice w/o fluoride (Control) & $318 \pm 39$ & - \\
\hline & Fluoride gel & $213 \pm 27$ & $33 \%^{a}$ \\
\hline & Duraflur & $203 \pm 34$ & $36 \%^{a}$ \\
\hline & Duraphat & $133 \pm 25$ & $58 \%{ }^{\mathrm{b}}$ \\
\hline & Fluorniz & $207 \pm 27$ & $35 \%{ }^{a}$ \\
\hline & Fluorphat & $212 \pm 27$ & $33 \%{ }^{a}$ \\
\hline & Duofluorid & $210 \pm 28$ & $34 \%{ }^{\circ}$ \\
\hline & Cariestop & $146 \pm 31$ & $54 \%{ }^{\mathrm{b}}$ \\
\hline & Fluoride toothpaste & $228 \pm 24$ & $28 \%^{a}$ \\
\hline
\end{tabular}

Different letters indicate significant differences $(p<0.05)$; w/o: without. 
The use of fluoride to control the development and progression of carious lesions has been investigated by several authors ${ }^{8,16,19}$ and topic applications have proved to be the most important form in combating these lesions. ${ }^{9,19}$

Enamel demineralization leads to the dissolution of hydroxyapatite and the diffusion of $\mathrm{Ca}$ and $\mathrm{P}$ ions on the enamel surface. The hypersaturation of these ions causes reprecipitation of hydroxyapatite, forming an intact superficial layer on the enamel surface. ${ }^{20}$ Thus, enamel remineralization is achieved through the presence of fluoride in the medium. ${ }^{19}$

Table 1 shows that all the treatments succeeded in reducing the depth of the lesions when compared with the control group. This reduction varied from $28 \%$ to $58 \%$. However, none of the products used here was able to completely prevent the formation of lesions, since lesions developed not only in the control group but also in the groups treated with fluoride products.

The Duraphat ${ }^{\circledR}$ fluoride varnish and Cariestop ${ }^{\circledR}$ silver diamine fluoride were the most effective, providing a reduction of about $58 \%$ and $54 \%$ in lesion depth, respectively. These results do not agree with those reported by Delbem et al. ${ }^{21}$ (2006), who, although using a different methodology than that of the present study, evaluated the effect of Duraphat ${ }^{\circledR}$ fluoride varnish and of Safluoride di Walter ${ }^{\circledR}$ silver diamine fluoride and found a lower mineral loss after application of the varnish than with the use of silver diamine fluoride. On the other hand, Coutinho ${ }^{22}$ (2002) did not find a significant difference between Duraphat ${ }^{\circledR}$ and silver diamine fluoride in either the extent or the depth of artificial carious lesions on the occlusal surface. Furthermore, Eronat et al. ${ }^{11}$ (1993) reported the superiority of fluoride varnishes in halting the progression of carious lesions when compared with other methods of topical application of fluoride.

Considering that calcium fluoride is the principal product resulting from a topical method of fluoride application, it can be inferred that the superiority of fluoride varnish (Duraphat ${ }^{\circledR}$ ) and of silver diamine fluoride (Cariestop ${ }^{\circledR}$ ) over the other fluoride products was due to the greater formation of calcium fluoride adsorbed on the enamel surface. The effectiveness of fluoride treatment depends little on the fluoride dosage and a great deal on its constant availability and effective action to promote remineralization, probably through the production of a greater deposition of fluoride on the teeth and the plaque. ${ }^{23}$ Furthermore, in addition to the formation of $\mathrm{CaF}_{2}$, silver diamine fluoride also produces silver phosphate, which increases the resistance of teeth against the progression of caries. ${ }^{24}$

The comparison of the national varnishes indicated that Duraflur ${ }^{\circledR}$ presented the best results. However, there was no significant difference in comparison to the other varnishes evaluated. These findings are in partial agreement with those of Medeiros, Mendonça $^{25}$ (1997), who reported that, among the national varnishes they evaluated, Duraflur ${ }^{\circledR}$ showed the best results. Similarly, other studies have shown reductions of $28 \%$ to $52 \%$ in the depth of lesions after the application of fluoride varnish..$^{12,16}$

The results of the comparison between $\mathrm{Du}^{-}$ raphat $^{\circledR}$ varnish and the fluoride gel were in partial agreement with the findings of Shobha et al. ${ }^{15}$ (1987), whose clinical evaluation of the preventive effect of Duraphat ${ }^{\circledR}$ fluoride varnish and fluoride gel demonstrated that Duraphat ${ }^{\circledR}$ was more effective. Similarly, Eronat et al. ${ }^{11}$ (1993) also found that Duraphat ${ }^{\circledR}$ presented better results than fluoride gel. However, Seppa et al. ${ }^{26}$ (1995) obtained different results, reporting they found no statistically significant difference when they compared the effect of fluoride gel and of fluoride varnish on caries in permanent teeth.

The importance of fluoride dentifrice in preventing and/or remineralizing initial caries lesions is well established in the literature. Based on this philosophy and aiming to minimize the ingestion of fluoride by young children in order to prevent dental fluorosis, toothpaste with a low concentration of fluoride has been developed. ${ }^{27}$ Several studies have shown that low-fluoride toothpastes do not present statistically significant differences in terms of their effect when compared with conventional toothpastes, and in addition to ensuring the same effectiveness, they also offer greater safety in terms of fluorosis. ${ }^{23,27}$ However, the effect of these toothpastes has not yet been compared with that of silver 
diamine fluoride, fluoride varnish and fluoride gel. From that standpoint, therefore, the present study used toothpaste containing a low concentration of fluoride (500 ppm F).

This fluoride toothpaste with a low fluoride concentration reduced the depth of the lesions less than did the national fluoride varnishes and the topically applied fluoride gel. However, this difference was not significant. A direct comparison of these results was not possible for lack of reports in the literature comparing the products evaluated in the present study. Nevertheless, we can make an analogy of our findings with those of Delbem et al. ${ }^{21}$ (2006), who, though using a different methodology from ours, made a comparative analysis of the cariostatic effect of fluoride gel and fluoride toothpaste and found no statistically significant difference between them.

With regard to the comparison between the fluoride toothpaste and the varnishes, it was found that Duraphat ${ }^{\circledR}$ varnish provided greater reduction of the depth of the lesion than the toothpaste and the national varnishes. However, although the national varnishes provided better results than the toothpaste, the difference between them was not statistically significant. These results are in partial agreement with those reported by Valença ${ }^{28}$ (1997), who evaluated the effect of different topical fluoride treatments on artificial caries lesions in bovine enamel, and found significantly greater remineralization in the groups treated with toothpaste and varnish than in those treated with mouth rinse solutions and with fluoride gel. In an evaluation of the effect of a combination

\section{References}

1. Habibian M, Roberts G, Lawson M, Stevenson R, Harris S. Dietary habits and dental health over the first 18 months of life. Community Dent Oral Epidemiol. 2001;29(4):239-46.

2. Quinonez RB, Keels MA, Vann WF Jr., McIver FT, Heller K, Whitt JK. Early childhood caries: analysis of psychosocial and biological factors in a high-risk population. Caries Res. 2001;35(5):376-83.

3. Vanobbergen J, Matens L, Lesaffre E, Bogaerts K, Declerk D. Assessing risk indicators for dental caries in the primary dentition. Community Dent Oral Epidemiol. 2001;29(6):424-34.

4. Ramos-Gomez FJ, Weintraub JA, Gansky SA, Hoover CL, Featherstone JD. Bacterial, behavioral and environmental of fluoride toothpaste and varnish on artificial carious lesions, Maia et al. ${ }^{29}$ (2003) reported that all the treatments, analyzed separately, were successful in increasing the hardness of the enamel surface.

The bioavailability of fluoride is important for its effect in the prevention of caries. ${ }^{19}$ However, this bioavailability depends on its solubility in the compounds and on the way it adheres to the compounds of the surface. ${ }^{30}$ Overall, therefore, the greater reduction in the depth of lesions promoted by varnishes, as opposed to toothpaste and fluoride gel, may have been due to the initial protection of the film of varnish and the reduced solubility of the enamel due to the absorption of the fluoride in the varnish, which confirms the results reported by Schmidt et al. ${ }^{13}$ (2002) and Demito et al. ${ }^{14}$ (2004).

Although the fluoride products reduced the depth of the artificial carious lesions, they did not completely prevent their development. It is important to emphasize that other preventive methods, such as controlling diet and plaque, should be considered in the prevention and/or control of dental caries disease.

\section{Conclusion}

All the fluoride products tested in this in vitro study promoted a reduction in the depth of the artificial carious lesions. However, none of the products used here was able to completely prevent the formation of lesions. The highest cariostatic effect was achieved by the fluoride varnish Duraphat ${ }^{\circledR}$ and the lowest by the fluoride toothpaste.

factors associated with early childhood caries. Caries Res. 2002;26(2):165-7.

5. Davies GN. Early childhood caries - a synopsis. Community Dent Oral Epidemiol. 1998;26 (1 Suppl):106-16.

6. de Almeida BS, da Silva Cardoso VE, Buzalaf MAR. Fluoride ingestion from toothpaste and diet in 1- to 3-year-old Brazilian children. Community Dent Oral Epidemiol. 2007;35(1):5363.

7. Cury J. Uso do flúor e controle da cárie como doença. In: Baratieri LN, Monteiro Junior S, Andrada MAC, Vieira LCC, Ritter $\mathrm{AV}$, Cardoso AC et al. Odontologia Restauradora: fundamentos e possibilidades. São Paulo: Santos; 2001. p. 31-68. 
8. Chedid S. Avaliação da quantidade de dentifrício fluoretado ou $\mathrm{NaF}$ a $0,02 \%$ no desenvolvimento de cárie em dentes decíduos: um estudo in vitro utilizando modelo de ciclagens de $\mathrm{pH}$ [Tese de Doutorado]. São Paulo: Faculdade de Odontologia da Universidade de São Paulo; 1999.

9. Rolla G, Saxegaard E. Critical evaluation of the composition and use of topical fluorides, with emphasis on the role of calcium fluoride in caries inhibition. J Dent Res. 1990;69:7805.

10. Suzuki T, Nishida M, Sobue S, Moriwaki Y. Effects of diammine silver fluoride on tooth enamel. J Osaka Univ Dent Sch. 1974;(14):61-72.

11. Eronat C, Eronat N, Alpoz AR. Fluoride uptake by enamel in vitro following application of various topical fluoride preparations. J Clin Pediatr Dent. 1993;17(4): 227-30.

12. Ogaard B, Duschener H, Ruben J, Arends J. Microradiography and confocal laser scanning microscopy applied to enamel lesions formed in vivo with and without fluoride varnish treatment. Eur J Oral Sci. 1996;104(4):378-83.

13. Schmidt JL, Staley RN, Wefel JS, Kanellis M, Jakobsen JR, Keenan PJ. Effect of fluoride varnish on demineralization adjacent to brackets bonded with RMGI cement. Am J Orthod Dentofacial Orthop. 2002;122(2):125-34.

14. Demito CF, Vivaldi-Rodrigues G, Ramos AL, Browman SJ. The efficacy of a fluoride varnish in reducing enamel demineralization adjacent to orthodontic brackets: an in vitro study. Orthod Craniofac Res. 2004;7(4):205-10.

15. Shobha T, Nandlal B, Prabhakar AR, Sudha P. Fluoride varnish versus acidulated phosphate fluoride for schoolchildren in Manipal. J Indian Dent Assoc. 1987;59(6-9):157-60.

16. Hicks J, Wild T, Flaitz CM, Seybold S. Fluoride and caries development in primary tooth enamel: an in vitro study. ASDC J Dent Child. 2001;68(5-6):304-10.

17. Mortimer KV. The relationship of deciduous enamel structure to dental disease. Caries Res. 1970;4(3):206-23.

18. Brown LJ, Wall TP, Lazar V. Trends in total caries experience: permanent and primary teeth. J Am Dent Assoc. 2001;131(2):223-31.

19. ten Cate JM. Current concepts on the theories of the mechanism of action of fluoride. Acta Odontol Scand. 1999;57(6):3259.
20. Arnold WH, Dorow A, Langenhorst S, Gintner Z, Bánóczy J, Gaengler P. Effect of fluoride toothpastes on enamel demineralization. BMC Oral Health. 2006;6:8.

21. Delbem ACB, Bergamaschi M, Sassaki KT, Cunha RF. Effect of fluoridated varnish and silver diamine fluoride solution on enamel demineralization: pH-cycling study. J Appl Oral Sci. 2006;14(2):88-92.

22. Coutinho TCL. Estudo in vitro do potencial cariostático dos selantes resinosos, dos cimentos ionoméricos, do diamino fluoreto de prata e do verniz fluoretado aplicado em superfície oclusal de molares permanentes humanos [Tese de Doutorado]. São Paulo: Faculdade de Odontologia de Bauru-USP; 2002.

23. Chow LC, Takagi S, Frukhtbeyn S, Sieck BA, Parry EE, Liao NS et al. Remineralization effect of a low-concentration fluoride rinse in an intraoral model. Caries Res. 2002;36(2):13641.

24. Shimizu A, Kawagoe MA. A clinical study of the effect of diammine silver fluoride on recurrent caries. J Osaka Univ Dent Sch. 1976;16:103-9.

25. Medeiros UV, Mendonça LVD. Formação in situ de fluoreto de cálcio a partir da utilização de vernizes fluoretados. Rev Bras Odontol. 1997;54(2):102-6.

26. Seppa L, Leppanen T, Hausen H. Fluoride varnish versus acidulated phosphate fluoride gel: a 3 -year clinical trial. Caries Res. 1995;29(5):327-30.

27. Alves KMRP, Pessan JP, Brighenti FL, Franco KS, Oliveira FAL, Buzalaf MAR et al. In vitro evaluation of the effectiveness of acidic fluoride dentifrices. Caries Res. 2007;41(4):2637.

28. Valença AMG. Efeito de diferentes tratamentos com fluoretos tópicos na remineralização de lesões artificiais de cárie: um estudo in vitro em ciclagem de $\mathrm{pH}$ [Tese de Doutorado]. Rio de Janeiro: Faculdade de Odontologia da Universidade Federal Fluminense; 1997.

29. Maia LC, de Souza IP, Cury JA. Effect of a combination of fluoride dentifrice and varnish on enamel surface rehardening and fluoride uptake in vitro. Eur J Oral Sci. 2003;111(1):6872.

30. Mühlemann HR, König KG, Marthaler TM, Schait A, Schmidt H. Schweiz Mschr Zahnheilk. 1960;70:1037-56. 